\title{
A Modernização Técnica do Mundo e o Projeto de Melhorar o Homem
}

Franz J. Brüseke ${ }^{1}$

Resumo

Entendemos a modernidade como sendo essencialmente técnica. Com isso apresentamos a modernidade política ou cultural, vinculada ao iluminismo, como um fenômeno exclusivamente europeu. Contra as implicações sociais evocadas pela modernização técnica estão sendo mobilizados recursos normativos contidos no "estoque cultural" das grandes civilizações. O projeto central de qualquer moral social é a adaptação do comportamento errático dos indivíduos a um standard considerado exemplar. Desta maneira, as imperfeições individuais são alvo contínuo de um projeto de "melhorar o homem". Projetos de transformação do homem daquilo o que ele é em algo que ele deve ser sempre provocam resistências, sejam elas conscientes e politicamente articuladas sejam elas resultados da simples inércia individual e coletiva. Com isso todas as tentativas de "melhorar o homem" travam as suas batalhas e desenvolvem métodos de intervenção, vigilância e punição. Os totalitarismos, europeus e extra-europeus, do século XX podem ser interpretados no campo tenso entre dois polos: o da modernização técnica e do projeto de melhorar o homem.

Palavras-chave: modernização técnica, racionalização, processo civilizatório

${ }^{1}$ Doutor em Sociologia. Professor do Departamento de Ciências Sociais da Universidade Federal de Sergipe e pesquisador do CNPq. 


\title{
The World's Technical Modernization and the Man Improvement Project
}

\begin{abstract}
We understand modernity as being essentially technical. Therefore we present the cultural and political modernity, linked to Enlightenment, as a phenomenon exclusively European. Against social implications raised by technical modernization are being mobilized normative resources contained in the "cultural stock" of great civilizations. The main project of any social moral is adaptation of individual's erratic behavior to a standard seen as an example. Thus, individual imperfections are ongoing target of a project to "improve the man". Projects that transforms the man the way he is into something that he must be always causes resistance, whether conscious and politically articulated whether results from the simple individual and collective inertia. Thus, all attempts to "improve man" fight their battles and develop intervention methods, surveillance and punishment. Twentieth century totalitarianism, European and extra-European, can be interpreted as a tense field between two poles: the technical modernization and the project to improve the man.
\end{abstract}

Keywords: technical modernization, rationalization, civilizing process

O ocidente, berço do capitalismo e força matriz da globalização racionalizante, deixou ao mundo contemporâneo um duplo legado. Por um lado, o ocidente revolucionou em escala planetária as estruturas sócio-econômicas e sócio-técnicas até que estas se tornassem compatíveis com as exigências daquilo que se apresenta hoje como economia moderna. Na medida em que este processo somente foi possível na base da destruição ou marginalização de "modos de produção" tradicionais e pelo preço da exploração e do desenraizamento, preço pago primeiramente pelas próprias populações europeias submetidas ao processo de 
industrialização surgiu desde o início um movimento paralelo, prático e teórico que se opôs a tal modernização. A Europa exportou, por assim dizer, o capitalismo e o socialismo, racionalizou e duvidou da própria racionalização, ou traduzido para uma conceituação mais diferenciada: a Europa deu início à globalização da modernidade técnica, gerando ao mesmo tempo sua crítica.

Essa crítica foi desde o início teórica e prática. Prática na medida em que "a questão social" forneceu motivo para a criação de redes de solidariedade e instituições compensatórias, normalmente sob tutela das diversas igrejas cristãs, e posteriormente consolidado e sistematizado, primeiramente na Alemanha sob Bismarck, enquanto iniciativa do estado na base de uma legislação, ainda embrionária, em prol da proteção contra as conseqüências de invalidez e doença, desemprego e velhice. 0 que foi posteriormente chamado Estado do Bem-Estar-Social foi concebido como um contraponto a um capitalismo selvagem sem moderação dos seus efeitos. Tanto o Keynesianismo, como a programática social-democrática pós-guerra e como a doutrina social da igreja católica com seu princípio de subsidiariedade são tradições da crítica européia ao capitalismo. A ambigüidade dessa crítica está, provavelmente, contida de forma mais vistosa no ideário do ordo-liberalismo, querendo unir a liberdade política e dos mercados com a ordem institucional e a solidariedade social.

É mais do que óbvio que, no século XIX até as vésperas da primeira guerra mundial, o sindicalismo dos operários, junto com a formação dos partidos políticos socialdemocratas reunidas na primeira e segunda Internacional, formam o foco da crítica política. Esses "movimentos", todavia nunca conseguiram sair da sua negatividade esperando a solução dos problemas de uma sociedade futura, além do capitalismo. Que sua existência pressionou os governos europeus, inclusive o de Bismarck, contribuindo assim indiretamente para o surgimento do Welfare State, não deve ficar sem registro. No contexto da nossa argumentação é de suma importância o fato que os "movimentos" social-democrata, 
socialista e (a partir de 1918) comunista são produtos das experiências particulares de países europeus com a modernização técnica. As repostas às mazelas sociais por ela evocada articulam-se em um leque diferenciado de opções críticas: abrangem o jacobinismo (1789) perpassando, como sua variante russa, o bolchevismo (1917) para se perder no totalitarismo de cunho estalinista; estão presentes no social-democratismo revolucionário, até 1914, até suas formas mais brandas de governismo reformista; e, não por último, encontram-se conservadas até hoje nas idéias da solidariedade e subsidariedade, tanto entre os ordo-liberais como no ideário político e social cristão.

As críticas ao capitalismo começam mudar suas feições quando se espalham primeiro pelos países ainda não industrializados da Europa e quando alcançam, finalmente, os países extra-europeus, entre eles muitas colônias ou ex-colônias da Inglaterra e França e de outros países europeus com menor raio de ação. Já Lênin tinha que adaptar sua leitura de Marx à um cenário bem diferente dos países da Europa central. A Rússia, país europeu que graças ao seu colonialismo continental tinha englobado parte da Ásia do norte, não dispunha de um setor industrial evoluído. Em conseqüência, o proletariado industrial e urbano era numericamente insignificante. Marx mesmo expressou diversas vezes seu desprezo sobre o atraso russo e esperava, conforme seu roteiro teórico, a revolução primeiramente em um país industrializado. Avaliação compartilhada por toda social-democracia até 1914, inclusive por Lênin, na época social-democrata russo exilado na Suíça. A adaptação do "marxismo" às necessidades da Rússia tinha que dar conta das massas populacionais que viviam no campo. A crítica ao capitalismo tornou-se, na Rússia, consequentemente uma crítica sem seu objeto central, o capitalismo industrial, analisado exaustivamente por Marx. Os bolcheviques conseguiram a façanha de manter essa crítica teórica em pé, promovendo ao mesmo tempo a modernização técnica das estruturas agrárias russas. De segura distância histórica é relativamente fácil perceber que essa adaptação do marxismo às 
"necessidades do primeiro estado dos operários e camponeses", tinha que abortar todo potencial crítico contido nele e transforma-lo numa doutrina de estado promovida por uma elite partidária que assumiu o papel exercido pela burguesia da Europa central, i.e. gerenciar a modernização técnica ou para ficar no jargão "desenvolver as forças produtivas".

Acontece que a burguesia europeia, influenciada por tradições aristocráticas mais antigas, não foi somente uma gerente técnica. Antes de mais nada, foram indivíduos oriundos dessa nova elite econômica e política que promoveram o que denominamos iluminismo. Enquanto os primeiros empresários praticavam a modernização técnica nas manufaturas herdadas por seus pais, ensaiaram os filósofos e escritores românticos a primeira grande revolta contra o ainda tímido processo de racionalização. Enquanto burgueses abriram comercialmente e por vezes violentamente o mercado mundial, preocupavam-se outros burgueses formular leis e constituições democráticas, como no caso da ex-colônia inglesa no norte das Américas, que deveriam garantir o bem-estar e a liberdade para todos; enquanto uns deixaram os ideais burgueses da liberdade, igualdade e fraternidade da revolução francesa morrer no terror das virtudes, tornaram-se outros, que eram também franceses e burgueses, os primeiros defensores dos direitos humanos. De ponto de vista de hoje parece fatal a total falta de percepção - na obra de Marx e outros críticos do capitalismo - do papel complexo das elites burguesas no processo da modernização técnica da Europa. Essa mistura entre racionalização violenta e a dúvida e crítica radical desse processo, unidos no mesmo momento histórico e articulados pela mesma categoria social fazem da história da Europa algo único e, aparentemente, difícil de entender.

Eventualmente, a compreensão da ambiguidade e singularidade da modernidade europeia, inclusive da impossibilidade de copiar ou repeti-la, torna-se mais fácil se observamos os percursos da modernização técnica no campo extra-europeu. Sob condi- 
ções do despotismo asiático, qualquer substituição das antigas elites políticas, precisava contar na sua empreitada (modernizante) com apoio social e político alternativo. Sem uma burguesia formada por um empresariado economicamente capitalista, politicamente esclarecido e culturalmente refinado e, segundo, sem um proletariado industrial numeroso e sindicalmente organizado esse apoio deveria vir da onde? Qual cultura política deveria aflorar em situação de confronto e, pior, de vitoria? Para uma mente sociologicamente treinada não é difícil de apostar no óbvio, que, todavia, se subtrai da percepção de muitos: o caminho da modernização técnica na Rússia e na China, sem seu embalo nas tradições europeias específicas somente poderia significar uma atualização das tradições despóticas asiáticas.

Consequentemente, a China em 1949, sob regime comunista de Mao Tse Tung, não perdeu muito tempo e promoveu desde o início a "revolução no campo". Entre a conquista do Palácio de Inverno a Longa Marcha perdeu-se a ilusão que o operário industrial europeu ia lidar a "revolução mundial" contra o capitalismo moderno. Em vez disso podemos observar, no caso da Rússia, um caminho semi-asiático da modernização técnica, no caso da China um caminho asiático na mesma direção. Vale a ressalva que os dois caminhos eram, em termos técnicos, bastante exitosos como, ao mesmo tempo dispendiosos em termos de vidas e de recursos, e por isso abandonado décadas depois. Que esse caminho real-socialista de modernização não segue uma determinação histórica podemos ver quando comparamos China e Japão que, uma vez militarmente vencido, não investiu tempo em experiências duvidosas e se entregou plenamente à modernização técnica, esforço que lhe rendeu durante muitos anos o título de vice entre as economias mais fortes do mundo, superado somente pelos USA.

Com o intuito de contribuir para um maior esclarecimento do caminho europeu da modernização e para liberar os debates sobre a modernização extra-europeia da sua fixação no modelo europeu queremos em seguir discutir sobre alguns aspectos da 
história peculiar da modernidade europeia e do espírito da modernidade técnica que se mostra como força matriz das grandes transformações globais. Nesta perspectiva não existe uma modernidade central tão pouco existe uma modernidade periférica, cada país e cada região têm a sua história que merece ser contada, não obstante, temos que constatar: a modernidade técnica é na sua matriz idêntica do Norte ao Sul. Como a empresa capitalista e o mercado em qual está inserida expressam a lógica de uma economia e administração altamente racionalizada, a técnica expressa o racionalismo científico na sua última versão. Que as diversas culturas e os indivíduos nelas inseridas, lutam, cada um de sua maneira, com os mecanismos e a lógica desta "grande transformação", eis o destino do nosso tempo.

Podemos constatar uma certa ansiedade conceitual nas discussões brasileiras sobre a "modernidade" que, de uma ou outra maneira, competem teoricamente com o conceito da "modernidade européia" introduzindo expressões como "modernidade periférica", "modernidade múltipla" e outros ou constatam a "inautenticidade da modernidade brasileira". ${ }^{2} \mathrm{Na}$ medida em que entendemos, em concordância com o conceito do agir técnico em Max Weber (SELL, 2010) e do conceito do desocultamento técnico em Heidegger (HEIDEGGER, 1953), o caráter técnico da modernidade perdem essas distinções sua importância e se revela a tecnicidade da modernidade como matriz daquele "sistema" ora em fase da sua plena globalização. Especificidades continentais, regionais ou locais, nesta perspectiva, não estão sendo negados, muito pelo contrário, a história cultural e política - analiticamente separada da, normalmente impactante, modernização técnica - recupera desta maneira sua singularidade e, assim dizer, dignidade teórica.

\footnotetext{
${ }^{2}$ A discussão brasileira sobre a modernidade é heterodoxa. Está vinculada principalmente com autores como Gilberto Freyre, Sergio Buarque de Holanda, Raimundo Faoro e, mais recentemente, Roberto DaMatta, cujas obras encontram eco, por vezes nitidamente crítico, em publicações de autores contemporâneos como Jessé Souza, Mauricio José Domingues, Leonardo Avritzer e Sergio Costa, entre outros.
} 
O voo rasante sobre séculos, acontecimentos, países e autores resulta necessariamente em maior distanciamento e simplificação, o que é sempre o preço da abstração e da teoria geral. Ao contragosto assumimos o risco de errar no detalhe para contribuir (eventualmente) para uma compreensão no nível da análise geral. Essa por sua vez é indispensável para nortear as pesquisas empíricas e imunizar estes contra sua instrumentalização nas lutas culturais contemporâneas guiadas por ressentimentos anti-ocidentais, compreensíveis na sua gênese, no entanto, infundadas teoricamente e politicamente insustentáveis.

Queremos lembrar que a sociedade contemporânea aparece na interpretação de muitos autores como consequência de um processo contínuo de racionalização. Esta levaria a uma combinação ótima de fatores de produção, aumentaria o valor heurístico do pensar científico, criaria uma rede cada vez mais densa de funções solidárias entre si, levaria a um controle crescente dos afetos em prol do refinamento dos costumes e garantiria em geral o progresso tecnológico, social e econômico.

A interpretação da sociedade moderna como produto da racionalização acompanha a sociologia desde os seus primórdios, não obstante, apontaram autores de renome, já na fase constitutiva da sociologia, para efeitos não intencionados do próprio processo de racionalização. Assim ela restringiria o bem-estar psicológico (FREUD), levaria a construção de uma gigantesca gaiola de ferro (WEBER), aumentaria a suscetibilidade da sociedade e da economia por crises (DURKHEIM, MARX) ou alienaria o homem de uma vida verdadeira e autêntica (ADORNO, HEIDEGGER). As interpretações críticas do processo de racionalização ganharam força em consequência de experiências negativas com certos aspectos do desenvolvimento tecnológico e da modernidade como tal. 0 que fortaleceu argumentos que apontavam a irracionalidade dos tempos modernos em detrimento da sua racionalização crescente (BRÜSEKE, 1991, 1996). Não por último radicalizou a crítica pós-moderna, as duvidas referentes à racionalidade da 
modernidade, crítica que se empenhou para denunciar a própria razão iluminista (SLOTERDIJK, MAFFESOLI, BAUMAN).

Sem dúvida, captam as teorias da racionalização a essência dos tempos modernos e nos revelam o porquê da sua inegável habilidade de se impor enquanto dinâmica globalizante. Não obstante, o "espírito do capitalismo" desaparece frequentemente atrás de uma nuvem de teorias mais variadas que, de uma ou outra forma, tentam entender o que aconteceu no berço do capitalismo e do racionalismo ocidental: a Europa. 0 problema, a nosso ver, começa aqui, pois a visão clara da dinâmica racionalizante começa ficar embaçada quando elementos políticos, culturais, históricos europeus se colocam no caminho do observador. As análises históricas revelam, sim, como alguns países da Europa se transformaram sob impacto da racionalização, mas misturam frequentemente singularidades européias com a essência da modernidade, que é técnica e racionalizante. Assim estão sendo avaliados as tradições iluministas como aspecto típico ou até essencial da modernidade, enquanto se trata de um sequência de eventos particularmente europeus, que dizem respeito a um nível normativo ou moral da própria Europa central, em especial da Grande Bretanha, da França e de menor porte, da Alemanha. $\mathrm{Na}$ Europa, e somente na Europa confundem-se de fato racionalização técnica e econômica com o iluminismo e suas ambições políticas e morais.

O “capitalismo" teve, no imaginário dos marxistas, um limite no futuro mas também no passado. A passagem da sociedade feudal para a produção fabril e a grande indústria marcava essa cisão. Marx descobriu, sem usar este conceito, a racionalidade da empresa moderna, motor das inovações permanentes tanto no campo da organização do trabalho quanto na tecnologia aplicada.

Aceitando a constatação teórica de uma mudança profunda no modo de produção das regiões situadas no centro da Europa, não quer dizer que, o que foi chamado posteriormente de capitalis- 
mo, caiu do céu. A sociedade industrial em formação foi diferente em alguns campi, mas não foi totalmente oposto as formações históricas anteriores. O capital, já era conhecido na sua forma comercial há milênios e um sistema bancário desenvolvido há séculos. Também o mercado, mecanismo de interligação de produtores distintos, é um fenômeno sócio-econômico arcaico e não característica exclusiva da sociedade moderna.

A grande novidade, no sentido estrito da palavra, era, em meados do século dezenove, o surgimento da grande indústria, um salto técnico que mostrou toda a sua força, primeiro, na Inglaterra e França, e depois na Alemanha. Curiosamente cumprimentaram Marx e seus discípulos o desenvolvimento das forças produtivas, como eles denominaram as indústrias crescentes, como sinal de um progresso histórico. Além disso, eles queriam ver essas forças produtivas libertadas dos seus entraves, identificadas como relações de produção capitalista.

Onde os economistas, inspirados por Marx, esperavam o limite da sociedade moderna, ela não apareceu, o processo de "valorização do valor" continua, e se importa pouco com suas crises temporárias ou regionais. O livro de Robert Kurz (1992), polêmica sobre o colapso da modernização, tem aqui um grande defeito. Kurz afirma novamente a velha teoria do fim do capitalismo, por causa de uma tendência inerente a ele, de implodir exatamente no momento da sua maior generalização.

O que está sendo discutido nas últimas décadas, sob o rótulo de globalização, tematiza exatamente isso: a eliminação das últimas ilhas até agora não integradas no grande mecanismo mundial de produzir e consumir. Formações sócio-econômicas pré-modernas desapareceram quase por completo, exceto algumas economias de subsistência em regiões afastadas das grandes aglomerações. Países que queriam implantar outra lógica econômica desistiram do próprio modelo, como a dissolvida União Soviética, ou tentam hoje uma integração não-catastrófica na 
sociedade global e sua maneira de organizar a economia. 0 "capitalismo" está perto de virar o único princípio econômico mundial, ultrapassando todos os limites dos estados territoriais, ainda existentes. Pois, o que se esconde atrás do "capitalismo" não é somente um principio imoral da exploração do trabalho humano, mas uma racionalidade técnica cuja abrangência data historicamente antes do capitalismo. 0 que chamamos capitalismo é um mecanismo econômico, portador de uma racionalização parcial, mais eficaz, no seu campo de validade, do que qualquer outra lógica econômica conhecida até então. A única crise que este mecanismo conhece é essa da sua própria racionalidade.

O que chamamos generalização do "capitalismo" apresenta-se para os cientistas sociais como um problema teórico. Um conceito tem somente um valor analítico, se ele possuir capacidade de diferenciação. Se todos os animais fossem pássaros, poderíamos esquecer o conceito de pássaro. Se todas as formações sócio-econômicas existentes podem ser caracterizadas como "capitalismo", temos que procurar outros conceitos capazes de distinguir entre os fenômenos macro-sociais da sociedade global. Pensando bem, não trata-se no caso do "capitalismo" de um conceito equivalente à denominação "socialismo", "democracia", "ocidente" ou semelhante. 0 "capitalismo" é somente o princípio que rege a empresa individual quando acoplado ao mercado e exposta à concorrência com outras empresas. Capitalista é somente a empresa e não a sociedade toda. O perspicaz Karl Marx intitulou sua obra principal consequentemente "O Capital" e não "O Capitalismo". O “capitalismo" não é um sistema político - como o comunismo ou a democracia ocidental - e por isso parece ser imune ao seu questionamento sistemático.

A afinidade do princípio capitalista com a modernidade técnica resulta da sua extrema adaptabilidade as mais diversas situações. Sua racionalidade, e seja ela somente parcial ou setorial, é a interface amigável com a tecnicidade da modernidade contemporânea. Podemos perguntar se as crises no "sistema financeiro 
internacional", para falar somente essas desde 2008, não revelam novamente a fragilidade sistêmica do "capitalismo". Sem a autorização científica de fazer prognósticos podemos afirmar o que interessa no contexto da nossa abordagem. Em caso de uma colisão entre a racionalidade da modernidade técnica e da irracionalidade ou disfuncionalidade de qualquer fenômeno social ou econômico estão sendo mobilizados os recursos técnicos da sociedade contemporânea. 0 Estado, enquanto estado racional (WEBER), tem nestas situações limites a sua grande hora. 0 "capitalismo selvagem" ou "capitalismo de cassino" quando entra na mira de uma nova onda racionalizante tende perder a disputa com os processos racionalizantes que são mais fortes do que ele. Se isso é uma lei histórica com validade infinita? Bem, responder a essa pergunta seria realmente profecia. A teoria da modernidade técnica não se apresenta como substituta de escatologias sociais às avessas.

II.

Contra as deficiências sociais evocadas pela modernização técnica estão sendo mobilizados recursos normativos contidos no "estoque cultural" das grandes civilizações. No caso do ocidente trata-se da maneira judaico-cristã de interpretar o homem no mundo. Assim, na filosofia da historia de Marx reencontramos uma escatologia cristã laicizada, como no ideário da revolução francesa um moralismo da solidariedade fraterna oriundo da mesma fonte. 0 projeto central de qualquer moral social é a adaptação do comportamento errático dos indivíduos a um standard considerado exemplar. Desta maneira, as imperfeições individuais são alvo contínuo de um projeto de "melhorar o homem". Esse projeto antecede o projeto marxiano de "melhorar o mundo" e encontra-se no humanismo europeu, com raízes na antiguidade.

O humanismo começa com os romanos que desenvolvem uma compreensão da humanitas influenciados pela paidéia dos gregos. Mas também autores como Goethe, Schiller, Marx ou Sartre 
são humanistas, pois se referem a uma essência do homem, seja ela baseada na grandeza das suas virtudes ou na liberdade encontrada na sociabilidade emancipada, quando defendem sua visão humanista. Até Sartre, invertendo uma afirmação metafísica de Platão quando diz: a existência precede a essência, fica preso na metafíscia, pois a inversão de uma afirmação metafísica não pode ser outra coisa senão metafísica. Criticar o humanismo, todavia, não significa defender o bárbaro ou bruto como oposto do humano. Para Heidegger o humanismo precisa ser criticado porque fica aquém das suas próprias possibilidades. Por enquanto vale: qualquer humanismo é resultado de uma metafísica ou no mínimo se apresenta como fundamento de uma nova metafísica. (HEIDEGGER, 1949/1991)

A crítica ao humanismo por Heidegger implica a interpretação do "humano", visto a partir da ontologia fundamental. Nesta perspectiva aparece o ser-aí enquanto estar lançado no aberto do Ser. Somente em contato com o aberto do Ser o conceito existência faz sentido e abri-se para o impensado e o sem fundamento. Assim a existência deixa de ser primeira instância ou fundamento para o essencial. 0 que precisa ser tirado do esquecimento é o próprio Ser. Mais ainda, Heidegger instiga a busca da verdade do Ser além das denominações "lógica", "valor", "mundo", "Deus" e coloca a reflexão sobre o "humanismo" em relação com o sã e o sagrado que se mostra, eventualmente, na clareira do Ser. Somente neste contexto o ethos pode ser recuperado e junto com ele a dignidade e valor próprio do homem.

Para Sloterdijk, o que chamamos humanismo é basicamente um fenômeno literário. Os gregos antigos letrados passaram para os romanos letrados as suas "cartas" filosóficas, poéticas e políticas. Os romanos por sua vez passaram essas "cartas" adiante usando pela primeira vez a expressão humanitas para a comunidade dos letrados e cultos. Formando desta maneira as bases do "humanismo" deram o conceito chave para uma educação literária que moldou a educação ginasial conforme os diversos 
canons literários das burguesias nacionais da Europa, entre a revolução francesa e a segunda guerra mundial. Hoje, todavia, vivemos numa época em que somente marginalmente a literatura e o ideário humanista fornece a síntese das sociedades massificadas. A cultura literária e humanista ainda existe mas somente enquanto subcultura de uma sociedade permeada por meios de comunicação eletrônica.

A pretensão do homem de se auto-superar vem de longe. No ocidente ouvimos cedo o apelo cristão de "vestir o novo homem"; em especial nas cartas do apóstolo Paulo, que, por sua vez, era resultado de uma autotransformação paradigmática: o perseguidor dos primeiros cristãos, Saulo, tornou-se Paulo, um novo homem com uma nova missão. Melhorar seu desempenho observado por um Deus irado moveu, também, os fieis e leitores do Velho Testamento que fizeram esforços diários para "não cair em tentação". Cometer um pecado era uma queda de um nível superior para um nível inferior. Através do arrependimento e auto-castigo; era possível compensar essa queda, todavia, era difícil superar a imperfeição humana. Esforços renovados eram necessários para manter o compasso com as exigências dos mandamentos e somente poucos chegaram a um status de quase-perfeição, mais perto da santidade do que os demais.

Qualquer projeto pedagógico, seja ele teoricamente explicitado ou somente inerente à tradição e hábitos de uma cultura singular, almeja o melhoramento do comportamento dos educandos. Também, quando escolas contemporâneas abrem mão da sua missão pedagógica, i.e., desistem de uma interferência sistemática para incentivar ou corrigir o comportamento dos seus alunos, administram um diferencial que as legitima. Este diferencial é a informação e as habilidades técnicas que os alunos desejam de adquirir e que as escolas e seus mestres oferecem. Nestes estabelecimentos, um up grade cognitivo contribui para o melhoramento do desempenho dos seus frequentadores. 
Uma vez sensibilizados para os procedimentos heterodoxos e culturalmente diversificados que visam o "melhoramento do homem", vamos identificar estes em inúmeras práticas individuais e em planos institucionais variados. Recentemente juntam-se a essas estratégias mais convencionais outras que estão diretamente vinculadas com as inovações tecnológicas das últimas décadas. Podemos basicamente distinguir entre duas opções fundamentais: a) tentativas de "melhorar o homem" através de manipulações da sua base fisiológica, em especial da sua sequência genética, dando assim continuidade a sua evolução biológica de forma assistida; e b) tentativas de "melhorar o homem" através da evolução de máquinas inseridas ou acopladas ao corpo humano visando a substituição parcial - ou hipoteticamente total - dele. No primeiro campo estão sendo travadas as batalhas sobre os pros e contras da eugenia, no segundo, surge a visão de um homem protético que em diversas utopias cibernéticas passaria potencialmente suas capacidades neurológicas para outro veículo técnico.

As frequentes incursões utópicas e fantasiosas nos campos do "melhoramento do homem" assustam os menos avisados e provocam frequentemente reações adversas. Não obstante, também se concedemos boas razões aos críticos das transformações tecnológicas em curso e se admitimos que a maior parte das utopias eugênicas e cibernéticas não passa, mesmo, de uma utopia técnica, temos que admitir que uma impactante mudança está se anunciando: uma transformação da imagem que o homem tem de se mesmo.

As projeções eugênicas, quando se limitam ao campo das medidas que diminuem problemas de saúde e contribuem para um prolongamento da vida, ainda não desafiam a imagem do antropos que nos é familiar. Pois, na medida em que sequências do DNA de origem animal podem ser integradas no DNA humano começam a ser tocados os limites entre o ser humano e o ser animal. Na perspectiva das possibilidades da biotecnologia aparece 
uma quimera transumana que para uns tem os traços simpáticos de um Avatar, para outros significa a perda total da identidade do homem. Somente o fato de que podemos hoje discutir se é vantajoso ou não manter as características da espécie humana já documenta as mudanças em curso.

A eugenia, emergida na primeira metade do século XX entre pesquisadores americanos e na Europa principalmente entre russos e alemães, teve, desde sua adoção pelos nacional-socialistas com a finalidade de manter a pureza de uma suposta "raça ariana”, exatamente a imagem da promoção genética de uma ideologia racial. Não surpreende tanto que, ainda em 1999, quando Peter Sloterdijk proferiu uma palestra em Schloss Elmau e perguntou se um melhoramento genético do homem seria possível, as ondas da indignação percorreram a opinião publicada da Alemanha. Onde uns acreditaram poder pegar um proto-fascista in flagrante revelou-se, à revelia do politicamente correto, um pensamento complexo e original sobre a antropo-técnica que foi apresentada na sua mais recente e completa versão na obra "Você deve mudar sua vida!" (SLOTERDIJK, 2009).

A ideia de construir um "novo homem" pode ser denominada como a obsessão do século $X X$. A sua, por enquanto última, versão encontramos na prática e teoria do gender mainstreaming ${ }^{3}$. Nela pretende-se alcançar um ideal humano além da sua polarização biológica em feminino e masculino. "Não se nasce mulher. Torna-se mulher" já sabia Simone de Beauvoir ${ }^{4}$ e a simples ampliação dessa tese na direção do homem masculino apresenta também este como produto das circunstâncias e, senão, de intervenções pedagógicas. Uma vez liberada a existência humana da sua condição biológica abre-se de fato um vasto campo para experiências inusitadas, fantasias desenfreadas e manipulações

\footnotetext{
${ }^{3}$ Butler, Judith. Gender Trouble: Feminism and Subversion of Identity. New York: Routledge, 1999.
}

${ }^{4}$ Beauvoir, Simone de. 0 segundo sexo. Paris: Gallimard, 1949. 
ideológicas. Essas ganham um potencial totalitário por causa da "transversalidade" da questão de gênero que faz dela um veículo político ágil e potencialmente onipresente. O "totalitarismo" do gender mainstreaming vai muito além da pretensão feminista clássica de "emancipar a mulher", pois a idéia da emancipação no contexto do igualitarismo moderno ainda partiu de uma compreensão da "identidade" da mulher e, consequentemente, do homem. A subversão da identidade dos sexos femininos e masculinos aponta de sua maneira particular na direção do novo homem, que, antes de ser "vestido", tem que ser desnudado e desconstruído.

Projetos de transformação do homem daquilo o que ele é em algo que ele deve ser sempre provocam resistências, sejam elas conscientes e politicamente articuladas sejam elas resultados da simples inércia individual e coletiva. Com isso todas as tentativas de "melhorar o homem" travam as suas batalhas e desenvolvem métodos de intervenção, vigilância e punição. Inicialmente, o comunismo soviético ainda tentou convencer, através da escrita e retórica, às pequenas camadas urbanas e letradas da antiga Rússia de desistir da sua pretensão de serem elites. As camadas camponesas, ou as populações não-russas como os cossacos do Don ou os colonos alemães da Volga foram submetidas, sem grande cerimônia, à uma bio-política radical. Pois, a remoção dos seus corpos dos seus antigos territórios, a deportação e concentração dos mesmos em lugares nefastos, conseguiu senão criar um novo "homem soviético" pelo menos destruir o velho de forma sustentada. Essa prática bio-política se voltou cada vez mais, também, contra as resistências e dissidências intelectuais ou de qualquer outra natureza. Toda via sem grande sucesso ao longo prazo. Aparentemente é o controle sobre os corpos insuficiente para garantir a hegemonia do novo homem. A obsessão do século XX precisava ser refinada para poder vingar. 
III.

Neste contexto é oportuno se lembrar das interpretações psico-analíticas do processo civilizatório a partir da sua unidade menor, o indivíduo. Este seria o agente de uma transformação de energias psíquicas brutas, libidinosas, em obras culturais refinadas. Consequentemente, uma teoria civilizatória "erotizante" pode interpretar a sublimação como positivo para o processo histórico dos costumes, apesar do potencial altamente neurotizante da crescente controle dos afetos, na perspectiva do próprio Freud. De Norbert Elias até Herbert Marcuse vai essa "erotização" da interpretação do processo civilizatório, apesar da inversão da teoria freudiana pelo último. Para Marcuse a dessublimação levaria à uma satisfação direta dos trabalhadores transformados em consumidores, enfraqueceria sua emancipação política e cultural e levaria a uma nova forma de repressão. Mas vamos voltar por um momento ao fundador da psicanálise para entender melhor a crítica e a proposta de Peter Sloterdijk, que relativiza a perspectiva freudiana opondo o Thymos ao Eros. No seu ensaio Drei Abhandlungen zur Sexualtheorie, de 1905, Sigmund Freud introduz o conceito de sublimação. Na psicanálise, designa este conceito desde então uma transformação de energias sexuais em um desempenho psíquico no campo intelectual, artístico ou, em geral, cultural. Essa canalização da libido possui extrema relevância para o processo sócio-histórico (FREUD, 1905/1961, p. 53). Freud atribui à libido um significado semelhante ao da fome; essa "fome sexual", inerente a cada indivíduo humano, está, todavia, distribuída de forma desigual, i.e., difere individualmente e depende da idade e do gênero. Freud deixa bem claro que a sublimação não explica o fazer cultural no que tange a seu conteúdo, não obstante, fornece as suas energias e motivações mais gerais (WAELDER, 1963/1969). Um elevado grau de libido não garante de antemão um alto nível de sublimação. Em constelações desfavoráveis, o Eu pode gastar todo seu tempo e suas forças para cercear e controlar as demandas libidinosas vindo do Id. Essa situação, com alto potencial neu- 
rótico, nem leva a uma satisfação sexual direta e nem consegue conduzir o libido a um nível refinado de prazer. Também, o mero deslocamento das energias libidinosas não leva automaticamente a um desempenho culturalmente valorizado. Sublimação, no sentido do uso deste conceito por Freud, quer realmente apontar na direção de um trabalho e um esforço do Eu de alcançar objetivos culturalmente valiosos, tendo para isso a sua disposição as energias libidinosas, que dificilmente revelam sua origem sexual. A sublimação, também, não se refere a uma total repressão de qualquer prazer sexual explícito. Nas suas cinco lições sobre psicanálise alerta Freud para os danos que isso traria para nossa saúde: "A plasticidade dos componentes sexuais, manifesta na capacidade de sublimarem-se, pode ser uma grande tentação a conquistarmos maiores frutos para a sociedade por intermédio da sublimação contínua e cada vez mais intensa. Mas assim como não contamos transformar em trabalho senão parte do calor empregado em nossas máquinas, de igual modo devemos esforçar-nos em desviar a totalidade da energia do instinto sexual (Sexualtrieb, ou pulsão sexual) da sua finalidade própria. Nem o conseguiríamos. E se o cerceamento da sexualidade for exagerado, trará consigo todos os danos de uma exploração abusiva" (FREUD, 1997, p. 60).

É bom lembrar que até a sublimação bem sucedida, apesar dos seus méritos socialmente reconhecidos, não garante a felicidade plena. Nos seus escritos culturais, em especial no "Mal Estar na Cultura", concede Freud que a frustração do princípio do prazer pelas mais variadas conquistas civilizatórias, limita o bem-estar individual, fato que parece se impor como uma invariável da condição humana.

Sloterdijk chama atenção para a "ira" que Homero menciona na primeira frase da Iliade. A menis (ira) no entendimento dos gregos na época do Homero - então muito antes do Platão - ainda não é domesticada nem é, na verdade, algo julgado negativo ou sinal de um descontrole psíquico, que uma pessoa madura de- 
veria evitar. A menis que move o Aquiles não faz dele um mero instrumento, no entanto, ela é para os gregos, parecida com uma energia invasiva, considerada uma dádiva divina. 0 guerreiro tem que ganhar uma relação consciente com a menis, assim ela passa da mera cólera e torna-se a fonte da audácia, da coragem e da força que o herói precisa para vencer em campo de batalha. Com os avanços da racionalização na filosofia grega, o carisma da menis enfraquece; a mania da contemplação da idéias entra no seu lugar e o expulsa, assim a grande ira da cultura (SLOTERDIJK, 2008).

A domesticação da ira leva agora a uma concepção nova da masculinidade, assim alimenta sua energia canalizada a coragem viril ou, em contextos de aglomerações urbanas, vai muito além disso e transforma-se na simples e necessária auto-afirmação do cidadão. Essa domesticação da menis exige a introdução de um conceito novo, para expressar as novas atitudes que alimentadas por ela. Sloterdijk propõe a palavra thymos e em conseqüência a thymotica como ciência da ira contemporânea. A thymotica tematiza, nos dois sexos, seu orgulho, sua coragem, sua atitude exigente, sua imposição, seu sentimento de honra, sua insistência na dignidade própria, sua disposição para a luta, seu orgulho e, não por último, suas ambições vingativas. Com isso ainda não esgotamos o complexo thymótico que, indo muito além daquilo que associamos normalmente com "ira" está sendo apresentado por Sloterdijk como o antípoda do complexo erótico-libidinoso, conceitualizado pela psicanálise freudiana.

Em sociedades complexas valorizam os atores seus recursos thymóticos como orgulho e auto-estima. Sob essa premissa uma vizinhança harmoniosa somente é possível quando dois atores ou coletivos se ignoram mutuamente. Uma vez rompida o véu da ignorância mutua estabelecem-se relações de comparação. 0 outro torna-se fator de estresse na medida em que pode ignorar o reconhecimento daquilo que e caro mim. Afirmações do valor próprio e demonstrações de indignação são a resposta conseqüente. Verdadeiras instituições e uma "política exterior" vão 
ritualizar os relacionamentos sob tensão thymótica para evitar erupções de violência que são, todavia, possíveis. Foi Hegel que cunhou o conceito de reconhecimento - conceito revitalizado por Axel Honneth e usado para travar as lutas contemporâneas pelo reconhecimento. Sloterdijk volta-se contra essa vertente que, na sua perspectiva, interpretaria o intersubjetivismo com, em última análise, categorias psicoanalíticas, i.e. eroto-dinâmicas. Ele recomenda de tentar entender as transações entre atores a partir de uma teoria thymotológica. Ambições podem sofrer modificações comunicativas ou eróticas, mas tem uma natureza sui generis que somente uma teoria thymótica pode esclarecer.

O século XX, em especial a sua primeira metade, pode ser interpretado, na perspectiva de Sloterdijk, como uma sequência de catástrofes thymóticas que acontecem, quando as instituições que civilizam as tensões fracassam. A causa deste fracasso era principalmente o radicalismo idealista e materialista que prometeu satisfação da ira coletiva através de caminhos até então desconhecidos. Alemanha, Rússia e China, para mencionar somente os principais, se transformaram desta maneira em verdadeiros coletivos da ira. Driblando as instâncias que normalmente moderam as tensões, parlamentos, debates públicos, tribunais etc. ofereceu a militância radical a liberação de energias vingativas, ressentimentos recalcados e fantasias de extermínio do outro. 0 fracasso da civilização da ira nos moldes comuns (religiosos, culturais, institucionais) foi somente um aspecto da crise thymótica que abateu Europa e vastas partes do mundo, pois essa crise não surgiu espontaneamente nem era uma erupção gratuita. Sloterdijk sublinha que uma verdadeira política da ira planejava as catástrofes que aconteceram. Sistematicamente canalizavam os partidos radicais do cunho comunista e nacional-socialista o ódio na direção das futuras vitimas. Para isso burocracia, organização e rotina eram indispensáveis. De certa maneira a política e economia do ressentimento é o segredo psico-político do século XX. 
Sloterdijk não reclama para si a descoberta da importância política do ressentimento; aponta Friedrich Nietzsche como observador crítico primeiro do nascimento do "espírito da vingança" da moral contemporânea cristã. 0 próprio desejo de vingança é tal antiga como a própria humanidade e documentado em inúmeras obras e fontes, todavia se restringe normalmente a um nível individual ou familiar-tribal. 0 "espírito da vingança" começa aflora em grande estilo somente com os tempos modernos quando os próprios modernos se voltam contra aquilo que representa a causa do atraso, ou melhor, quando estão sendo identificados os autores do "sofrimento e da injustiça". Ensaia se primeiro tímido e depois, no século XIX e XX, de forma mássica e sistematica o ódio a toda uma época (a feudal e depois a capitalista), à classes sociais inteiras (a burguesia, os gulags etc.) ou contra países representantes da ordem injusta (Grã Bretanha, USA etc.). Nesta época, não tem mais uma instância metafísica que chama o direito à vingança para si. "Minha é a vingança, diz o Senhor." Não é mais o juizo final que promete punir os culpados e restaurar a ordem moral danificada; não existe mais a expectativa que depois da morte seria resolvido o problema da injustiça mundana. Não, em tempos modernos acontece a vingança dos "humilhados e ofendidos" no horizonte temporal histórico e de preferência ainda durante a minha vida. Não surpreendem mais tanto as explosões da ira na Alemanha, Rússia, China ou Camboja, denominados por Sloterdijk "universos de aniquilação". Este olhar para trás é inquietante, pois ele revela que as mesmas estruturas thymóticas que levaram a essas erupções violentas históricas continuam existindo. "E quem queria negar que hoje já estão se formando as nuvens, das quais vão surgir as tempestades do século XXI" (SLOTERDIJK, 2008, p.73). 


\section{Referências Bibliográficas}

BRÜSEKE, Franz Josef. Chaos und Ordnung im Prozess der Industrialisierung. Skizzen zu einer Theorie globaler Entwicklung. Politische Soziologie; Sven Papcke e Arno Klönne, editores. Münster: LIT-Verlag, 1991.

BRÜSEKE, Franz Josef. A lógica da decadência. Desestruturação sócio-econômica, o problema da anomia e o desenvolvimento sustentável. Prefácio de Octávio Ianni. Belém: Editora CEJUP, 1996.

FREUD, Sigmund. Drei Abhandlungen zur Sexualtheorie. Frankfurt: Fischer, 1905/1961.

FREUD, Sigmund. Cinco Lições de Psicanálise. Rio de Janeiro: Imago Editora, 1997.

HEIDEGGER, Martin. Über den Humanismus. Frankfurt: Klostermann, 1949/1991.

HONNETH, Axel. Der Kampf um Anerkennung. Zur moralischen Grammatik sozialer Konflikte. Frankfurt: Suhrkamp, 1992.

KURZ, Robert. 0 colapso da modernização. Rio de Janeiro: Paz e Terra, 1992.

SELL, Carlos Eduardo. Máquinas petrificadas: Max Weber e a sociologia da técnica. Scientiae Studia (USP), v. 09, p. 563-583, 2011

SLOTERDIJK, Peter. Die Verachtung der Massen. Versuch über Kulturkämpfe in der modernen Gesellschaft. Frankfurt: Suhrkamp, 2000.

SLOTERDIJK, Peter. Zorn und Zeit. Frankfurt: Suhrkamp, 2008.

WAELDER, Robert. Die Grundlagen der Psychoanalyse. Frankfurt: Fischer, 1963/1969.

Recebido em 01.09.213

Aprovado em 15.10.2013 
